ONLINE MUTATION REPORT

\title{
Novel germline mutations in the adenomatous polyposis coli gene in Polish families with familial adenomatous polyposis
}

\author{
A Plawski, J Lubiński, T Banasiewicz, J Paszkowski, D Lipinski, A Strembalska, G Kurzawski, \\ T Byrski, S Zajaczek, D Hodorowicz-Zaniewska, T Gach, I Brozek, D Nowakowska, E Czkwaniec, \\ P Rrokowicz, M Drews, J Zeyland, W Juzwa, R Słomski
}

$\mathrm{F}$ amilial adenomatous polyposis (FAP) is a genetically determined disorder that is inherited in an autosomal dominant manner. The occurrence of FAP is associated with mutations in the $A P C$ gene, which were described in 1991. ${ }^{1}$ De novo mutations of the APC gene occur in one per 10000 newborns. The $A P C$ gene is localised on chromosome $5 \mathrm{q} 21$ and consists of 21 exons. In most cases, mutations of the $A P C$ gene are small deletions or insertions: the AAAGA deletion at codon 1309 , which occurs in $10 \%$ of families with FAP, and the ACAAA deletion at codon 1061, which occurs in $5 \%$ of families with FAP, are the most frequent mutations. Ninety-two percent of all mutations in the APC gene lead to truncations of the APC protein product. Dysfunction of the $A P C$ gene causes the accumulation of B-cathenin and the expression of genes that promote cell division.

The FAP syndrome contributes only a relatively low percentage of all colorectal carcinomas $(1-2 \%)$ and is characterised by the presence of numerous (at least 100) polyps that line the mucosa of the large intestine and rectum. The occurrence of other gastrointestinal adenomas, cutaneous sebaceous cysts, osteomas (mostly in the jaw, scapula, and long bones), connective tissue neoplasms, desmoid tumours, and, in some cases, coexisting duodenal and thyroid carcinomas (which together are classified as Gardner syndrome) and less common structural deformations in the teeth may also be observed..$^{2}$ The DNA bank of Polish families with FAP was established in 1997 at the Institute of Human Genetics, Polish Academy of Science in Poznań.

This study reports a spectrum of mutations of the APC gene in Polish patients with FAP.

\section{MATERIAL AND METHODS \\ Patients}

Clinical diagnoses of FAP in patients were established in genetic centres or gastroenterology clinics in Poznań, Szczecin, Kraków, Wrocław, Gdańsk, Warszawa, and Lódź, appropriate to the patients' place of residence. Families with FAP came from the following regions of Poland: 79 from the central west, 17 from the northwest, seven from the south east, six from the southwest, two from the north, and nine from the central east. To date, samples from 315 people from 120 families with FAP have been collected in the Polish FAP DNA bank. In this group, 140 patients had typical FAP, while eight patients had atypical FAP. Mutations in the APC gene were analysed in 120 probands. If mutations were identified in a proband, the members of the proband's families were also screened (if available).

\section{Molecular methods}

We extracted DNA from peripheral blood cells with the classical phenol purification method. We screened fragments of the APC gene that encompassed exons 5-8, exons 10-14,

\section{Key points}

- The aim of this study was to investigate mutations in the adenomatous polyposis coli (APC) gene in the Polish DNA bank for families with FAP.

- 120 Polish families with familial adenomatous polyposis (FAP) were screened for mutations in the part of the APC gene that encompasses exons 5-8, exons 1014 , and the $3^{\prime}$ part of exon 15. DNA was screened with heteroduplex analysis, single strand conformational polymorphism methods, and DNA sequencing.

- Mutations in the APC gene were found in 42 (35\%) Polish families with FAP, and 22 types of mutation in the APC gene were identified. Of these, 15 mutations were deletions of 1-11 base pairs, five were insertions of 1-8 base pairs, and two were substitutions. Overall, 14 of the identified mutations were not seen in other populations. De novo mutations occurred in three families; one of these mutations had not been described before.

- Most of the detected mutations in $88 \%$ are localised at the $5^{\prime}$ end of exon 15 of the APC gene.

and the fragment from A to L of exon 15 of the APC gene for mutations with heteroduplex analysis and single strand conformational polymorphism methods. DNA fragments that showed heteroduplex in heteroduplex analysis or additional patterns in single strand conformational polymorphism analysis were sequenced by direct polymerase chain reaction product sequencing and analysed with ALFExpress (Amersham-Pharmacia Biotech, Uppsala, Sweden) according to the manufacturer's specifications. New mutations were confirmed to be absent in 50 unrelated people in the control group, which consisted of 25 unrelated women and 25 unrelated men randomly chosen from the Polish population.

\section{RESULTS AND DISCUSSION}

We initially analysed DNA from 120 probands in the DNA bank for mutations in the APC gene. Mutations were found in $42(35 \%)$ probands (table 1). We identified 22 types of mutations in the group studied; 14 of these were not seen in other populations. Five mutations recurred in the families that we examined (table 2). In three families, probands had de novo mutations.

Most mutations were found in the $5^{\prime}$ region of exon 15; in addition, two mutations were found in exon 5 , one in exon 8 , and one in exon 11. No mutations outside exon 15 had been described previously. In exon 11 , we saw insertion $\mathrm{T}$ in position 1491 in two families. In both families, differences 
Table 1 Mutations of APC gene detected in Polish families with FAP

\begin{tabular}{|c|c|c|c|c|c|c|c|}
\hline Case & Family \# & Patient \# & Age of onset & Cancerous features outside the colon & $\begin{array}{l}\text { Exon and } \\
\text { fragment }\end{array}$ & Mutation & Stop codon \\
\hline 1 & 045 & 9045 & NDA & - & 5 & 601delG & 204 \\
\hline 2 & 017 & 9017 & 26 & - & 5 & 636delA & 218 \\
\hline 3 & 089 & 9089 & NDA & - & 8 & 892-893delCA & 325 \\
\hline \multirow[t]{6}{*}{4} & 001 & 9001 & 35 & Desmoid tumour and cerebral flax tumour & 11 & 1491 ins $T$ & 608 \\
\hline & & 9002 & 37 & - & 11 & 1491 ins T & 608 \\
\hline & & 9003 & 47 & - & 11 & 1491 ins $T$ & 608 \\
\hline & & 9004 & 36 & - & 11 & 1491 ins $T$ & 608 \\
\hline & & 9005 & 16 & - & 11 & $1491 \mathrm{ins} T$ & 608 \\
\hline & & 9033 & 36 & - & 11 & 1491 ins T & 608 \\
\hline \multirow[t]{3}{*}{5} & 129 & 9129 & 10 & Brain fibromatosis and ossis tempoparietalis & 11 & 1491 ins T & 608 \\
\hline & & 9129,1 & 12 & - & 11 & 1491 ins T & 608 \\
\hline & & 9129,2 & 12 & - & 11 & 1491 ins T & 608 \\
\hline 6 & 050 & 9050 & NDA & NDA & $15 \mathrm{~B}$ & $2413 C>T$ Arg $>$ Stop & 805 \\
\hline 7 & 023 & 9023 & 16 & NDA & $15 \mathrm{C}$ & 2509 delC & 915 \\
\hline 8 & 031 & 9031 & NDA & NDA & $15 \mathrm{C}$ & $2626 \mathrm{subC}>\mathrm{T}$ & 876 \\
\hline \multirow[t]{3}{*}{9} & 043 & 9043 & 30 & - & $15 \mathrm{C}$ & 2626 subC $>T$ & 876 \\
\hline & & 9043,1 & - & - & $15 \mathrm{C}$ & $2626 \mathrm{subC}>\mathrm{T}$ & 876 \\
\hline & & 9043,5 & - & - & $15 \mathrm{C}$ & 2626 subC $>T$ & 876 \\
\hline 10 & 130 & 9130 & NDA & NDA & $15 \mathrm{D}$ & 2922 insG & 975 \\
\hline 11 & 051 & 9051 & NDA & NDA & $15 \mathrm{D}$ & 3119-3126insCTCTGGAA & 1058 \\
\hline 12 & 102 & 9102 & - & - & $15 \mathrm{E}$ & 3164-3168delTAATA & 1057 \\
\hline \multirow{2}{*}{13} & 028 & 9028 & 28 & - & $15 \mathrm{E}$ & 3183-3187delACAAA & 1062 \\
\hline & & 9028,1 & - & - & $15 \mathrm{E}$ & $3183-3187$ delACAAA & 1062 \\
\hline 14 & 067 & 9067 & 19 & NDA & $15 \mathrm{E}$ & 3183-3187delACAAA & 1062 \\
\hline 15 & 093 & 9093 & - & - & $15 \mathrm{E}$ & 3183-3187delACAAA & 1062 \\
\hline 16 & 108 & 9108 & - & - & $15 \mathrm{E}$ & 3183-3187delACAAA & 1062 \\
\hline 17 & 111 & 9111 & - & - & $15 \mathrm{E}$ & $3183-3187$ delACAAA & 1062 \\
\hline 18 & 088 & 9088 & NDA & - & $15 \mathrm{E}$ & 3202-3205del TCAA & 1124 \\
\hline 19 & 106 & 9106 & 26 & - & $15 \mathrm{E}$ & 3202-3205del TCAA & 1124 \\
\hline 20 & 011 & 9011 & 19 & Thyroid & $15 \mathrm{~F}$ & 3473-3474delGA & 1162 \\
\hline \multirow[t]{3}{*}{21} & 041 & 9041 & 13 & - & $15 \mathrm{E}$ & 3371 delA & 1225 \\
\hline & & 9041,4 & - & - & $15 \mathrm{E}$ & 3371 delA & 1225 \\
\hline & & 9041,5 & - & - & $15 \mathrm{E}$ & 3371 delA & 1225 \\
\hline 22 & 058 & 9058 & 36 & - & $15 \mathrm{~F}$ & 3515delA & 1181 \\
\hline 23 & 083 & 9083 & NDA & - & $15 \mathrm{~F}$ & 3578-3581 delCAGT & 1264 \\
\hline 24 & 080 & 9080 & NDA & - & $15 \mathrm{~F}$ & 3613delA & 1264 \\
\hline \multirow[t]{2}{*}{25} & 146 & 9146 & 8 & - & $15 \mathrm{G}$ & 3921-3924Del AAAA & 1319 \\
\hline & & 9146,1 & 4 & Duodenal polyps & $15 \mathrm{G}$ & 3921-3924Del AAAA & 1319 \\
\hline 26 & 059 & 9059 & 18 & - & $15 \mathrm{G}$ & 3927-3931 del AAAGA & 1312 \\
\hline \multirow[t]{2}{*}{27} & 065 & 9065 & 36 & - & $15 \mathrm{G}$ & 3927-3931 del AAAGA & 1312 \\
\hline & & 9065,1 & 12 & - & $15 \mathrm{G}$ & 3927-3931 del AAAGA & 1312 \\
\hline 28 & 069 & 9069 & NDA & NDA & $15 \mathrm{G}$ & 3927-3931 del AAAGA & 1312 \\
\hline 29 & 071 & 9071 & 36 & NDA & $15 \mathrm{G}$ & 3927-3931 del AAAGA & 1312 \\
\hline 30 & 075 & 9075 & NDA & NDA & $15 \mathrm{G}$ & 3927-3931 del AAAGA & 1312 \\
\hline 31 & 032 & 9032 & NDA & NDA & $15 G$ & 3927-3931 del AAAGA & 1312 \\
\hline 32 & 036 & 9036 & 13 & - & $15 G$ & 3927-3931 del AAAGA & 1312 \\
\hline 33 & 016 & 9016 & 20 & - & $15 \mathrm{G}$ & 3927-3931 del AAAGA & 1312 \\
\hline 34 & 103 & 9103 & 26 & Liver and lung & $15 \mathrm{G}$ & 3927-3931 del AAAGA & 1312 \\
\hline 35 & 104 & 9104 & - & - & $15 \mathrm{G}$ & 3927-3931 del AAAGA & 1312 \\
\hline 36 & 105 & 9105 & 20 & - & $15 \mathrm{G}$ & 3927-3931 del AAAGA & 1312 \\
\hline 37 & 118 & 9118 & NDA & - & $15 \mathrm{G}$ & 3927-3931 del AAAGA & 1312 \\
\hline 38 & 147 & 9147 & NDA & - & $15 \mathrm{G}$ & 3927-3931 del AAAGA & 1312 \\
\hline 39 & 149 & 9149 & NDA & - & $15 \mathrm{G}$ & 3927-3931 del AAAGA & 1312 \\
\hline 40 & 030 & 9030 & 31 & Desmoid tumour and stomach polyps & $15 \mathrm{H}$ & 4266-4276delTCTTCCAGATA & 1433 \\
\hline 41 & 123 & 9123 & NDA & NDA & $15 \mathrm{H}$ & $4386-4387$ Ins GA & 1462 \\
\hline 42 & 027 & 9027 & 45 & Desmoid tumour and stomach polyps & 151 & 4667 INS A & 1558 \\
\hline
\end{tabular}

were seen in the age of onset of polyps. In family 9129, symptoms were noted when patients were 10 and 12 years old, while in family 9001, symptoms were noted later (table 1). Different genetic backgrounds in these families must have influenced the time of onset of the disease. In both families, probands had brain cancer, and proband 9001 also had a desmoid tumour, which is linked with mutations located between codons 1403 and 1578p; in both cases in our study, the affected proband had a mutation in exon $11 . .^{2-4}$

The mutation 636delA in exon 5 is a new mutation that occurred de novo in family 9017. We detected two other de novo mutations in the Polish population: $2413 \mathrm{C}>\mathrm{T}$ ( $\operatorname{Arg}>$ Stop) and 4393-4394Ins GA both were described in 1996 by Dobbie and colleagues. ${ }^{5}$ The youngest patient with FAP who we studied was a girl who at the age of four years already had numerous polyps in the colon and sparse duodenal polyps and who was a carrier for the known mutations 39213924delAAAA.

The most frequent mutations in Polish families with FAP were 3927-3931del AAAGA (del $5 \mathrm{bp}$ at 1309), which occurred in $15(12.5 \%)$ families, and 3183-3187delACAAA (del 5 bp at 1061), which was seen in six (5\%) families. The frequency of these mutations varies depending on populations. The frequency of the most common deletion, $5 \mathrm{bp}$ at 1309 , in other populations varies from $0 \%$ in northwest Spain through $2.4 \%$ in Australian populations, 5\% in Dutch populations, and $7 \%$ in Israeli populations up to $16 \%$ in the group reported by Varsco and colleagues..$^{6-9}$ The deletion 5 bp at 1061 also occurs with a range of frequencies: for example, $0 \%$ in northwest Spain, $1.5 \%$ in Israeli populations, and $8.4 \%$ 


\begin{tabular}{|c|c|c|c|c|c|}
\hline Number & Exon & Mutations & Stop & Recurrence & References \\
\hline 1 & 5 & 601delG & 204 & 1 & $\mathrm{New}^{*}$ \\
\hline 2 & 5 & 636delA & 218 & 1 & New \\
\hline 3 & 8 & 892-893delCA & 325 & 1 & New \\
\hline 4 & 11 & 1491 ins $T$ & 608 & 2 & New \\
\hline 5 & 15 & $2413 C>T$ Arg $>$ Stop & 805 & 1 & 5 \\
\hline 6 & 15 & 2509delC & 915 & 1 & New \\
\hline 7 & 15 & 2626 subC $>T$ & 876 & 2 & $13,27-30$ \\
\hline 8 & 15 & 2922insG & 975 & 1 & New \\
\hline 9 & 15 & $\begin{array}{l}3119-31261 \mathrm{NS} \\
\text { CTCTGGAA }\end{array}$ & 1058 & 1 & New \\
\hline 10 & 15 & 3164-3168delTAATA & 1057 & 1 & 31,32 \\
\hline 11 & 15 & 3183-3187delACAAA & 1062 & 6 & $1,31,33$ \\
\hline 12 & 15 & 3202-3204del TCAA & 1124 & 2 & 14 \\
\hline 13 & 15 & 3371 delA & 1225 & 1 & New \\
\hline 14 & 15 & 3473-3474delGA & 1162 & 1 & New \\
\hline 15 & 15 & 3515delA & 1181 & 1 & New \\
\hline 16 & 15 & 3578-3581 delCAGT & 1264 & 1 & New \\
\hline 17 & 15 & 3613delA & 1264 & 1 & New \\
\hline 18 & 15 & 3921-3924Del AAAA & 1319 & 1 & 34 \\
\hline 19 & 15 & 3927-3931 del AAAGA & 1312 & 15 & 1 \\
\hline 20 & 15 & $\begin{array}{l}\text { 4266- } \\
\text { 4276delTCTTCCAGATA }\end{array}$ & 1433 & 1 & New \\
\hline 21 & 15 & 4393-4394Ins GA & 1462 & 1 & New \\
\hline 22 & 15 & 4667 INS A & 1558 & 1 & 35,36 \\
\hline
\end{tabular}

in Australia. ${ }^{6-8}$ A study of more than 100 Dutch families showed equal frequency of these most frequent mutations. In another study of 680 families from Germany, the two most frequent mutations had frequencies of $4.9 \%$ for deletion $5 \mathrm{bp}$ at 1061 and $7 \%$ for deletion $5 \mathrm{bp}$ at $1309 .{ }^{10}{ }^{11}$ In our group, the deletion 5 bp at 1309 occurred more than twice as frequently as the deletion $5 \mathrm{bp}$ at 1061. In worldwide populations, differences in the frequency of these two mutations are seen. Polish populations of patients with FAP belong to the group in which both mutations occur with high frequency. ${ }^{12}$

In exon 15, we saw another two recurrent mutations, each in two families. One was a $2626 \mathrm{C}>\mathrm{T}$ substitution and the other a 3202-3205delTCAA. ${ }^{13}{ }^{14}$ Mutations in the region between codons 1445 and 1578 are associated with the occurrence of numerous features outside the colon (desmoid tumours, osteomas, epidermoid cysts, and upper gastrointestinal polyps), which are classified as Gardner syndrome. ${ }^{23}$ In this region of the gene, we identified two mutations: 43864387insGA in the 9123 family (de novo) and 4667insA in the 9027 family. One of those families (9027) had features of Gardner syndrome, while the patients from family 9123 did not have any cancerous features outside the colon. The second case of Gardner syndrome had a mutation outside the expected region: a TCTTCCAGATA deletion that started at codon 1422 and lead to the stop codon at codon 1433(fig 1). This may indicate that the region responsible for Gardner syndrome cannot be determined exactly. In Polish patients
A

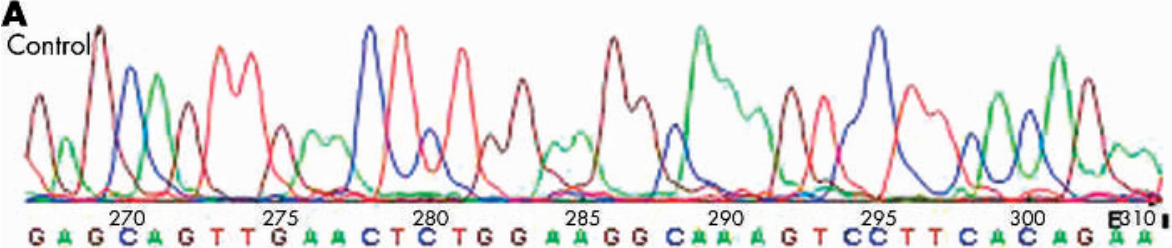

Figure 1 Mutations detected in Polish population: largest insertions detected in Polish population 31193126insCTCTGGAA (A) and largest deletions detected in Polish population 4266-4277delTCTTCCAGATA (B).
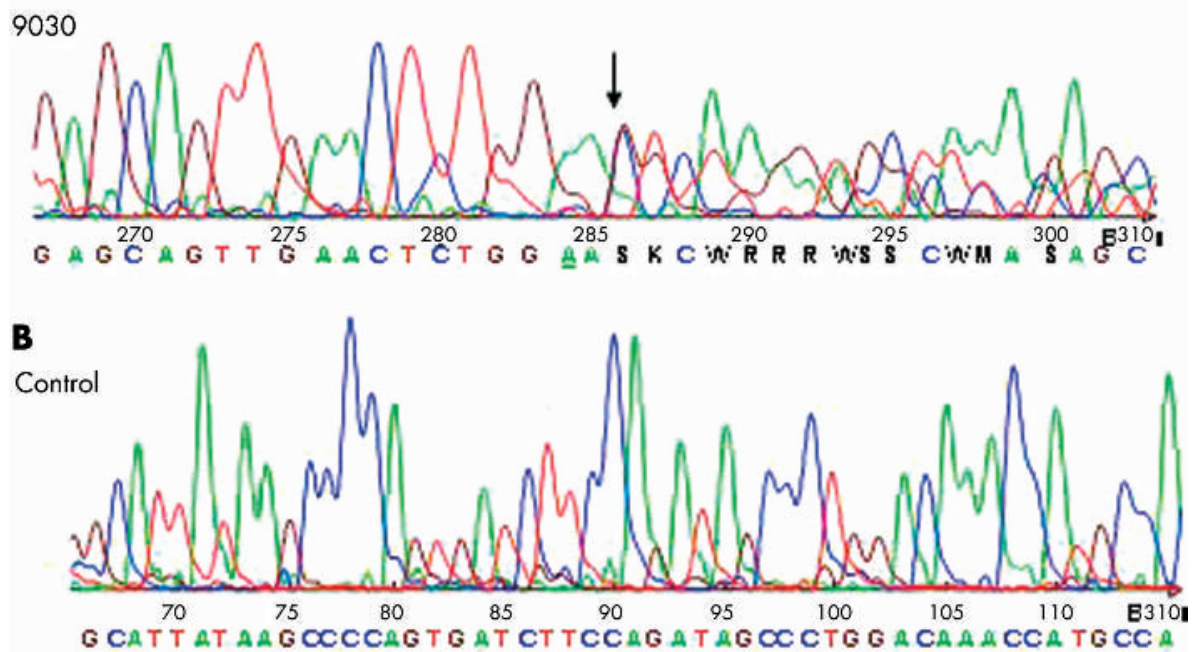

9051

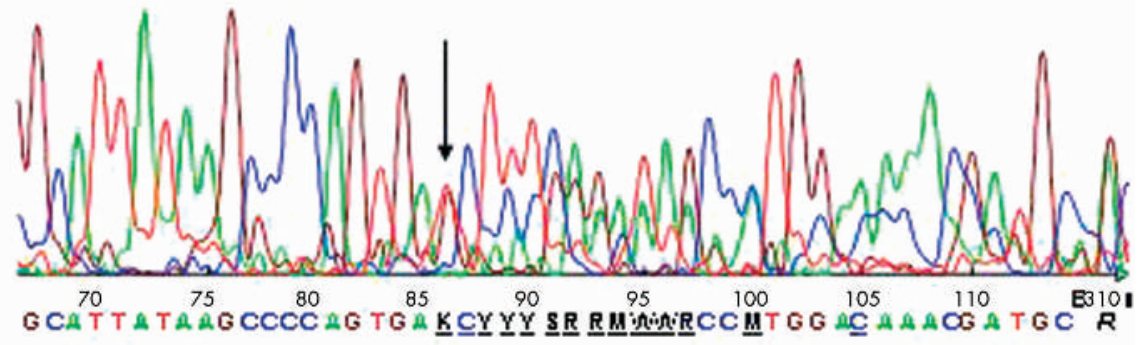


with FAP, most of the detected mutations were localised at the $5^{\prime}$ end of exon 15 of the APC gene. Of the detected mutations, $50 \%$ were in the fragment that encompassed nucleotides 1040 to 1309. In our group of patients, we did not see mutations in exons $6,7,10,12,13$, and 14, in which mutations were expected with the frequency of $1-2 \%$ on the basis of their occurrence in other populations. ${ }^{15}$

In our study, we examined 120 Polish families with FAP for the occurrence of mutations in the APC gene. For costefficiency reasons, we screened only the part of the $A P C$ gene in which mutations were most expected. Exon 9 of the $A P C$ gene was omitted, because of the absence of late onset of the disease and of variations in phenotypic manifestations in the identified families, which are characteristic for mutations in exon $9 .{ }^{16-18}$ The study region was chosen on the basis of previous studies in other populations, especially the report published by Wallis and colleagues, which considered $>200$ families with FAP from the United Kingdom. ${ }^{15} 1920$

We found mutations in $35 \%$ of the families we studied. A study in the biggest referred group from Germany reported mutations in $48 \%$ of 680 studied families. ${ }^{11}$ The percentage of detected mutations in our study was lower, which could have been caused by the occurrence of mutations outside the studied region or the lower efficiency of the methods we used to detect mutations. In all of the abovementioned studies in other populations, in vitro translation was used for mutation screening, and differences in rates of mutation detection ranged from $30 \%$ to $85 \% .^{11} 152122$ In our study, known polymorphic single base substitutions were visible during the analysis (data not shown), but the detected rate of substitutions in the studied group was low compared with the large German study (3/120 v 87/680). ${ }^{11}$ This can be attributed to the efficiency of the applied methods or the occurrence of mutations specific for Polish families with FAP.

To rule out the occurrence of large deletions, structural rearrangements of $A P C$ gene, or reduced expression of one allele of the APC gene in Polish patients with FAP as a frequent cause of FAP in Poland is impossible. ${ }^{23} 24$ In addition, the occurrence of recessive mutations in other genes (for example, the $M Y H$ gene), especially in de novo cases ( $>25 \%$ in our group), may contribute to the occurrence of the disease. ${ }^{25}{ }^{26}$ Further studies to look at the remaining regions of the $A P C$ gene and to search for large deletions in Polish families with FAP will be necessary. A study of recessive mutations of the $M Y H$ gene will have to be performed in families who lack mutations in the $A P C$ gene as the next step towards explaining causes of FAP in Poland.

\section{ACKNOWLEDGEMENTS}

The studies were financed by State Committee of Scientific Research Project KBV No6PO5A13021.

\section{Authors' affiliations}

A Plawski, D Lipinski, J Zeyland, W Juzwa, R Slomski, Institute of Human Genetics Polish Academy, Poznań, Poland

I Brożek, Department of Biology and Genetics, Medical University of Gdańsk, Gdańsk, Poland

D Hodorowicz-Zaniewska, T Gach, 1st Department of General and GI Surgery, Jagiellonian University, Cracov, Poland

A Strembalska, Genetic Department, Medical University Wroclaw, Wroclaw, Poland

D Nowakowska, Genetic Counselling Unit, Cancer Center and Institute of Oncology, Warsaw, Poland

E Czkwaniec, Department of Pediatrics and Gastroenterology, Institute of Polish Mother's Memorial Hospital, Lódz, Poland

G Kurzawski, T Byrski, S Zajaczek, J Lubiński, Department of Genetics and Pathology, Pomeranian Academy of Medicine, Szczecin, Poland T Banasiewicz, J Paszkowski, P Krokowicz, M Drews, 3rd Clinic of Surgery, Academy of Medicine, Poznań, Poland
Correspondence to: Dr A Plawski, Institute of Human Genetics, Polish Academy of Sciences, ul. Strzeszynska 32, 60-479 Poznan, Poland; andp@man.poznan.pl

Received 3 May 2003

Accepted 12 June 2003

\section{REFERENCES}

1 Groden J, Thliveris A, Samowitz W, Carlson M, Gelbert L, Albertsen H, Joslyn G, Stevens J, Spirio L, Robertson M, Sargeant L, Krapcho K, Wolff E, Burt R, Hughes JP, Warrington J, McPherson J, Wasmuth J, Le Paslier D, Abderrahim $H$, Cohen D, Leppert $M$, White R. Identification and characterization of the familial adenomatous polyposis coli gene. Cell 1991;66:589-600.

2 Caspari R, Olschwang S, Friedl W, Mandl M, Boisson C, Boker T, Augustin A, Kadmon M, Moslein G, Thomas G. Familial adenomatous polyposis: desmoid tumours and lack of ophthalmic lesions (CHRPE) associated with APC mutations beyond codon 1444. Hum Mol Genet 1995;4:337-40.

3 Davies D, Armstrong J, Thakker N, Horner K, Guy S, Clancy T, Sloan PL, Blair V, Dodd C, Warnes T. Severe Gardner syndrome in families with mutations restricted to a specific region of the APC gene. Am J Hum Genet 1995;57:1151-8

4 Kohoutova M, Stekrova J, Jirasek V, Kapras J. APC germline mutations identified in Czech patients with familial adenomatous polyposis. Hum Mutat 2002; 19:460-1.

5 Dobbie Z, Spycher M, Mary J-L, Haner M, Guldenschuh I, Hürlimann R, Amman R, Roth J, Müller HJ, Scott R. Correlation between the development of extracolonic manifestations in FAP patients and mutations beyond codon 1403 in the APC gene. J Med Genet 1996;33:274-80

6 Gavert N, Yaron Y, Naiman T, Bercovich D, Rozen P, Shomrat R, Legum C, Orr-Urtreger A. Molecular analysis of the APC gene in 71 Israeli families: 17 novel mutations. Hum Mutat 2002;19:664.

7 Schnitzler M, Koorey D, Dwight T. Frequency of codon 1061 and codon 1309 APC mutations in Australian familial adenomatous polyposis patients. Hum Mutat 1998;(suppl 1):S56-7

8 Ruiz-Ponte C, Vega A, Carracedo A, Barros F. Mutation analysis of the adenomatous polyposis coli (APC) gene in northwest Spanish patients with familial adenomatous polyposis (FAP) and sporadic colorectal cancer. Hum Mutat 2001; 18:355

9 Varesco L, Gismondi V, James R, Robertson M, Grammatico P, Groden J, Casarino L, De Benedetti L, Bafico A, Bertario L, Sala P, Sassatelli R, Ponz de Leon M, Biasco G, Allegretti A, Aste H, De Sanctis S, Rosetti C, Illeni M, Sciarra A, Del Porto G, White R, Ferrara G. Identification of APC gene mutations in Italian adenomatous polyposis coli patients by PCR-SSCP analysis. Am J Hum Genet 1993;52:280-5.

10 Van der Luijt RB, Khan PM, Vasen HF, Tops CM, van Leeuwen-Cornelisse IS, Wiinen JT, van der Klift HM, Plug RJ, Griffioen G, Fodde R. Molecular analysis of the APC gene in 105 Dutch kindreds with familial adenomatous polyposis: 67 germline mutations identified by DGGE, PTT, and southern analysis. Hum Mutat 1997:9:7-16.

11 Friedl W, Caspari R, Sengteller M, Uhlhaas S, Lamberti C, Jungck $M$, Kadmon M, Wolf M, Fahnenstich J, Gebert J, Moslein G, Mangold E, Propping P. Can APC mutation analysis contribute to therapeutic decisions in familial adenomatous polyposis? Experience from 680 FAP families. Gut 2001;48:515-21.

12 Nagase H, Nakamura Y. Mutations of the APC (adenomatous polyposis coli) gene. Hum Mutat 1993;2:425-34.

13 Prosser J, Condie A, Wright M, Horn JM, Frantes JA, Wyllie AN, Dunlop MG. APC mutation analysis by chemical cleavage of mismatch and a protein truncation assay in familial adenomatous polyposis. $\mathrm{Br} J$ Cancer 1994;70:841-6.

14 Paul P, Letteboer T, Gelbert L, Groden J, White R, Coppes MJ. Identical APC exon 15 mutations result in a variable phenotype in familial adenomatous polyposis. Hum Mol Genet 1993;2:925-31.

15 Wallis YL, Morton DG, McKeown CM, Macdonald F. Molecular analysis of the APC gene in 205 families: extended genotype-phenotype correlations in FAP and evidence for the role of APC amino acid changes in colorectal cancer predisposition. J Med Genet 1999;36:14-20.

16 Young J, Simms LA, Tarish J, Buttenshaw R, Knight N, Anderson GJ, Bell A, Leggett $B$. A family with attenuated familial adenomatous polyposis due to a mutation in the alternatively spliced region of APC exon 9. Hum Mutat 1998;11:450-5.

17 Rozen P, Samuel Z, Shomrat R, Legum C. Notable intrafamilial phenotypic variability in a kindred with familial adenomatous polyposis and an APC mutation in exon 9. Gut 1999;45:829-33.

18 Van der Luijt RB, Vasen HF, Tops CM, Breukel C, Fodde R, Meera Khan P. APC mutation in the alternatively spliced region of exon 9 associated with late onset familial adenomatous polyposis. Hum Genet 1995;96:705-10.

19 Fodde R, van der Luijt R, Wijnen J, Tops C, van der Klift H, van LeeuwenCornelisse I, Griffioen G, Vasen H, Khan PM. Eight novel inactivating germ line mutations at the APC gene identified by denaturing gradient gel electrophoresis. Genomics 1992;13:1162-8.

20 Olschwang S, Laurent-Puig P, Groden J, White R, Thomas G. Germ-line mutations in the first 14 exons of the adenomatous polyposis coli (APC) gene. Am J Hum Genet 1993;52:273-9.

21 O'Sullivan MJ, Mulcahy TM, Cambell J, O'Suilleabhain CB, Kirwan WO, Doyle CT, McCarthy TV. Detection of five novel germline mutations of the APC gene in Irish familial adenomatous polyposis families. Hum Mutat 1998;(suppl 1):S251-3. 
22 Powell SM, Petersen GM, Krush AJ, Booker S, Jen J, Giardiello FM Hamilton SR, Vogelstein B, Kinzler KW. Molecular diagnosis of familial adenomatous polyposis. N Engl J Med 1993;329:1982-7.

23 Su L-K, Steinbach G, Sawyer JC, Hindi M, Ward PA, Lynch PM. Genomic rearrangements of the APC tumor-suppressor gene in familial adenomatous polyposis. Hum Genet 2000;106:101-7.

24 Cao X, Eu KW, Seow-Choen F, Zhao Y, Cheah PY. Topoisomerase-I- and Alumediated genomic deletions of the APC gene in familial adenomatous polyposis. Hum Genet 2001;108:436-42.

25 Ohtsubo T, Nishioka K, Imaiso Y, Iwai S, Shimokawa H, Oda H, Fujiwara T, Nakabeppu Y. Identification of human MutY homolog (hMYH) as a repair enzyme for 2-hydroxyadenine in DNA and detection of multiple forms of hMYH located in nuclei and mitochondria. Nucleic Acids Res 2000;28:1355-64.

26 Jones S, Emmerson P, Maynard J, Best JM, Jordan S, Williams GT, Sampson JR, Cheadle JP. Biallelic germline mutations in MYH predispose to multiple colorectal adenoma and somatic G:C-->T:A mutations. Hum Mol Genet 2002;11:2961-7.

27 Nordling M, Engwall Y, Wahlström J, Wiklund L, Eriksson MA, Gustavsson B, Fasth S, Larsson PA, Martinsson T. Novel mutations in the APC gene and clinical features in Swedish patients with polyposis coli. Anticancer Res 1997; 17:4275-80

28 Valanzano R, Cama A, Volpe R, Curia MC, Mencucci R, Palmirotta R, Battista P, Ficari F, Mariani-Costantini R, Tonelli F. Congenital hypertrophy of the retinal pigment epithelium in familial adenomatous polyposis. Novel criteria of assessment and correlations with constitutional adenomatous polyposis coli gene mutations. Cancer 1996:78:2400-10.

29 Ficari F, Cama A, Valanzano R, Curia MC, Palmirotta R, Aceto G, Esposito DL, Crognale S, Lombardi A, Messerini L, Mariani-Costantini R, Tonelli F,
Battista P. APC gene mutations and colorectal adenomatosis in familial adenomatous polyposis. Br J Cancer 2000;82:348-53

30 Furuuchi K, Tada M, Yamada H, Kataoka A, Furuuchi N, Hamada J, Takahashi M, Todo S, Moriuchi T. Somatic mutations of the APC gene in primary breast cancers. Am J Pathol 2000;156:1997-2005.

31 Miyoshi Y, Ando H, Nagase H, Nishisho I, Horii A, Miki Y, Mori T, Utsunomiya J, Baba S, Petersen G, Hamilton SR, Kinzler KW, Vogelstein B, Nakamura Y. Germ-line mutations of the APC gene in 53 familial adenomatous polyposis patients. Proc Natl Acad Sci U S A 1992;89:4452-6.

32 Mandl M, Paffenholz R, Friedl W, Caspari R, Sengteller M, Propping P. Frequency of common and novel inactivating APC mutations in 202 families with familial adenomatous polyposis. Hum Mol Genet 1994;3:181-4.

33 Wakatsuki S, Sasano H, Matsui T, Nagashima K, Toyota T, Horii A. Adrenocortical tumor in a patient with familial adenomatous polyposis: a case associated with a complete inactivating mutation of the APC gene and unusual histological features. Hum Pathol 1998;29:302-6.

34 Walon C, Kartheuser A, Michils G, Smaers M, Lannoy N, Ngounou P Mertens G, Verellen Dumoulin C. Novel germline mutations in the APC gene and their phenotypic spectrum in familial adenomatous polyposis kindreds. Hum Genet 1997;100:601-5.

35 Bï̈rk J, Akerbrant $\mathrm{H}$, Iselius L, Bergman A, Engwall Y, Wahlstrom J, Martinsson T, Nordling M, Hultcrantz R. Periampullary adenomas and adenocarcinomas in familial adenomatous polyposis: cumulative risks and APC gene mutations. Gastroenterology 2001;121:1127-35.

36 Shitoh K, Konishi F, Miyaki M, lijima T, Furukawa T, Tsukamoto T, Nagai H. Pathogenesis of non-familial colorectal carcinomas with high microsatellite instability. J Clin Pathol 2000;53:841-5. 